\title{
APPLICATION OF COMPREHENSIVE BUDGET PREPARATION ON UMKM BATIK MALANG \\ (Study at UMKM Batik Blimbing - Malang)
}

\author{
Ulliyawatik \\ Department of Management FEB UMM \\ E-mail: ulliyawatik93@gmail.com
}

\begin{abstract}
This research was conducted for budgeting the comprehensive (Projected Sales Budget Sales, Production Budget, Budget Purchase of Raw Materials, Budget Direct Labor, Budget Overhead, Budget Marketing Costs, Budget and Administration General Budget of Income, Cash Budget, and Balance Sheet) at UMKM Batik Belimbing. Type of research is supporting a research case study using data analysis techniques comprehensive budget forecasting calculations. The method used by the comprehensive budget calculations. The purpose of this research to create a comprehensive budgeting UMKM Batik Blimbing 2016 and 2017.
\end{abstract}

Keywords: UMKM Batik Belimbing, Comprehensive Budget, Decision Making

\section{PENDAHULUAN}

Penyusunan anggaran merupakan hal yang penting bagi suatu perusahaan. Proses ini merupakan pembuatan rencana kerja dalam rangka waktu satu tahun. Anggaran disusun oleh manajemen dalam jangka waktu satu tahun yang akan membawa perusahaan ke kondisi tertentu yang diinginkan dengan sumber daya yang diperkirakan. Dengan anggaran, manajemen mengarahkan jalannya perusahaan ke suatu kondisi tertentu. Selain digunakan untuk perencanaan kerja perusahaan, penganggaran perusahaan juga koordinasi dan evaluasi kerja bagi serat sebagai alat untuk mendelegasikan wewenang atasan kepada bawahan.

Melihat perkembangan dunia usaha, anggaran sudah mulai digunakan diberbagai aspek baik itu perusahaan besar, organisasi, ataupun UMKM (Usaha Mikro Kecil Menengah). Penerapan anggaran di berbagai perusahaan, organisasi ataupun UMKM telah menjadi bukti bahwa penganggaran sangatlah penting dalam kegiatan suatu usaha atau organisasi.

Usaha Mikro Kecil Menengah (UMKM) kian merambah di berbagai daerah, perkembangan UMKM sudah menjadi hal yang dipertimbangkan oleh pemerintah daerah atau pusat agar dapat bersaing dalam pasar bebas yang akan mulai berjalan pada tahun 2016 mendatang, salah satu usaha pemerintah untuk mengembangkan potensi UMKM di berbagai daerah adalah dengan cara mengeluarkan kebijakan baru dimana pemerintah mulai memperhatikan dan mengembangkan UMKM sebagai Ekonomi Kerakyatan yang 
menjadi pilar bagi perekonomian daerah dan negara.

Pemberlakuan

MEA

(Masyarakat Ekonomi ASEAN), merupakan suatu celah dan tantangan bagi UMKM sebagai pilar ekonomi bangsa, pada awalnya UMKM belum diperhatikan pemerintah hingga pada akhirnya UMKM mulai terlihat sebagai penopang perekonomian bangsa dikala bangsa mengalami masa krisis.

Pemerintah telah menerapkan UMKM sebagai ekonomi kerakyatan, penyelenggaraan Rakorda yang telah dilakukan oleh pemerintah diharapkan dapat menjadi wadah bagi seluruh aspek masyarakat dan pemerintah agar dapat terus meningkatkan dan mengembangkan UMKM di suatu daerah.

Mengingat salah satu faktor yang penting dalam siklus kehidupan UMKM atau perusahaan adalah faktor keuangan yang jelas dan perputarannya dapat menghidupi kegiatan perusahaan dalam jangka pendek dan jangka panjang. Salah satu sistem yang dapat digunakan dalam manajemen keuangan UMKM adalah anggaran komprehensif, dimana dengan anggaran, manajemen dapat memproyeksikan dan mengarahkan perputaran keuangan UMKM dengan tepat.

UMKM Batik Blimbing adalah salah satu UMKM yang diharapkan dapat berperan besar bagi perekonomian didaerah Malang, akan tetapi dalam sistem keuangan UMKM ini masih belum melaksanakan sistem anggaran, sehingga UMKM ini tidak dapat melakukan perencanaan pengembangan usaha di masa yang akan datang.

UMKM batik blimbing menceritakan bahwa pemilik memiliki kesulitan dalam bidang pengaturan dan perencanaan keuangan usahanya. Dalam hal tersebut pemilik menginginkan adanya perencanaan keuangan yang mampu memberi manfaat untuk kedepannya. Pemilik memberikan saya kepercayaan untuk membuatkan sebuah perencanaan tersebut. Perencanaan keuangan komprehensif merupakan perencanaan yang tepat jika melihat apa yang diinginkan oleh pemilik UMKM.

Tuntutan UMKM untuk dapat terus berkembang dalam perekonomian kerakyatan sebagai pilar ekonomi bangsa untuk menghadapi pasar bebas dan Masyarakat Ekonomi ASEAN (MEA). Salah satu faktor yang dapat membantu UMKM agar bisa terus hidup dan berkembang yaitu sistem keuangan yang jelas dan tepat seperti sistem anggaran komprehensif, namun di dalam kegiatan usahanya belum menggunakan sistem keuangan yang jelas sehingga usahanya mengalami kesulitan dalam pengelolaan keuangan dan kesulitan dalam melakukan pengenmbangan usahanya.

\section{TINJAUAN PUSTAKA}

Anggaran yaitu rencana keuangan untuk masa depan, rencana tersebut mengidentifikasi tujuan dan tindakan yang diperlukan untuk mencapainya.Sebelum anggaran disiapkan, organisasi seharusnya mengembangkan suatu rencana strategis. Rencana strategis 
mengidentifikasi strategi-strategi untuk aktivitas dan operasi dimasa depan, setidaknya lima tahun ke depan. Organisasi dapat menerjemahkan strategi umum ke dalam tujuan jangka panjang dan jangka pendek. (Hansen, Mowen: 2009).

Sebuah sistem penganggaran memberikan beberapa manfaat untuk suatu organisasi (Hansen, Mowen : 2009); (1) Anggaran memaksa manajemen untuk merencanakan masa depan, (2) Menyediakan informasi yang dapat digunakan untuk memperbaiki pengambilan keputusan, (3) Anggaran memberikan standar yang dapat mengendalikan penggunaan berbagai sumber daya perusahaan dan memotivasi karyawan, dan (4) Memperbaiki komunikasi serta koordinasi.

Anggaran Komprehensif atau anggaran induk (master budget) adalah anggaran yang menggabungakan keseluruhan rencana organisasi. Anggaran induk merupakan sekelompokan anggaran parsial yang memiliki hubungan erat dan terintegrasi satu dengan yang lainnya dan dijadikan dasar untuk operasi perusahaan di dalam suatu periode di masa mendatang (Rudianto, 2009 : 196).

Komponen dalam anggaran komprehensif sebagai berikut; Anggaran penjualan, Anggaran produksi, Anggaran pembelian bahan baku, Anggaran tenaga kerja langsung, Anggaran overhead, Anggaran administrasi dan umum, Anggaran biaya pemasaran, Anggaran laba rugi, Anggaran kas, Proyeksi neraca.

\section{METODE PENELITIAN}

Jenis penelitian yang dilakukan adalah penelitian yang bersifat studi kasus, yaitu jenis penelitian yang berisikan paparan atau data yang relevan dari hasil penelitian pada obyek penelitian yang mencoba mengetahui dan memecahkan permasalahan yang ada. Lokasi penelitian adalah Batik Blimbing Malang yang beralamat di Jln. Candi Jago no. 5, Kecamatan Blimbing.

Berdasarkan urutan masalah yang telah dibahas sebelumnya, dalam menyusun anggaran komprehensif, maka variabel yang digunakan adalah anggaran penjualan, anggaran produksi, anggaran pembelian bahan baku, anggaran tenaga kerja langsung, anggaran overhead, anggaran administrasi dan umum, anggaran biaya pemasaran, anggaran laba rugi, anggaran kas, dan proyeksi neraca.

Setiap aspek dalam anggaran komprehensif mempunyai metode perhitungan masing -masing, anggaran penjualan yaitu rencana kerja perusahaan dimasa depan dalam periode tertentu di bidang penjualan produk perushaan. Dengan menggunakan metode Pertumbuhan rata-rata.

Anggaran produksi yaitu rencana perusahaan untuk mengahasilkan produk dalam jumlah yang sesuai dengan kebutuhan penjualan dengan mempertimbangkan jumlah persediaan awal dan akhir periode tertentu. Anggaran pembelian bahan baku yaitu penetapan biaya bahan baku, ditentukan oleh kebutuhan bahan baku dari setiap unit produk. 
Anggaran tenaga kerja langsung yaitu rencana pembayaran tenaga kerja dalam periode untuk memproduksi seluruh produk yang direncanakan. Anggaran overhead yaitu Seluruh biaya selain biaya bahan baku dan biaya tenaga kerja, yang direncanakan akan dibayarkan dalam satu periode tertentu. Anggaran administrasi dan umum yaitu rencana biaya yang berkaitan dengan aktivitas operasional kantor untuk mengatur dan mengendalikan organisasi secara umum.

Anggaran biaya pemasaran yaitu rencana pengeluaran yang berkaitan dengan seluruh aktivitas penjualan dan pendistribusian produk perusahaan. Anggaran laba rugi yaitu jumlah laba yang ingin diperoleh perusahaan melalui berbagai aktivitas operasional yang mencakup kegiatan produksi dan penjualan di dalam suatu periode tertentu. Dengan menggunakan metode a posteriori (penyusunan anggaran laba dimana jumlah laba ditetapkan sesudah proses perencanaan secara keseluruhan, termasuk penyusunan anggaran operasional).

Anggaran kas yaitu prediksi aliran kelua masuknya uang yang direncnakan perusahaan di dalam suatu periode tertentu, beserta penjelasan tentang sumber-sumber penerimaan dan pengeluaran kas tersebut. Metode yang digunakan adalah metode konsep dasar arus kas. Proyeksi neraca adalah prediksi jumlah dan rincian kekayaan yang akan dimiliki perusahaan beserta seluruh kewajibanya, baik kepada kreditor maupun kepada pemegang saham.

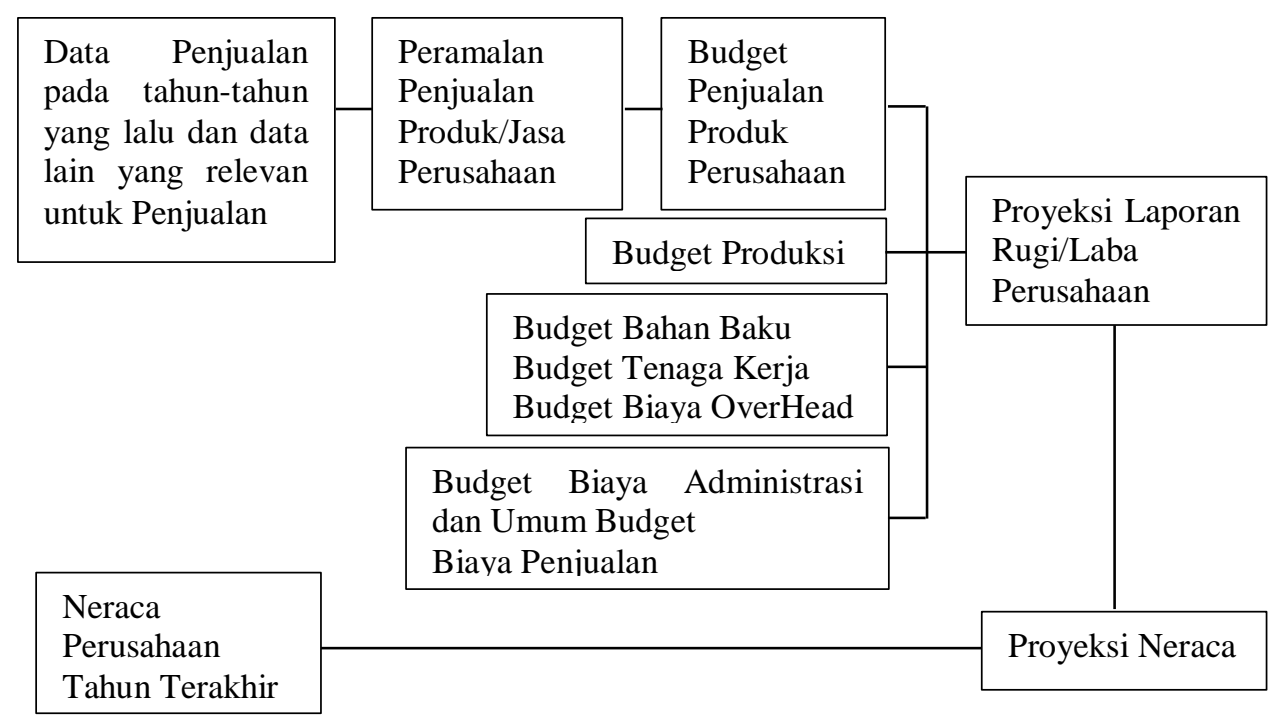

Gambar 1. Alur Penyusunan Penganggaran Komprehensif

Teknik pengumpulan data yang digunakan adalah pengumpulan data sekunder dan data primer. Data primer meliputi profil UKM Batik
Blimbing Malang dan data penjualan periode 2011-2014. Sedangkan data sekunder dalam penelitian ini berupa laporan penjualan, laporan bahan 
baku, laporan biaya tenaga kerja, dan laporan overhead, dan laporan biaya produksi perusahaan.

Teknik analisis data menggunakan peramalan anggaran perusahaan meliputi; anggaran penjualan dengan metode Least Square berpatokan dengan data histori yang cenderung mengalami perumbuhan setiap tahunnya. Pada metode ini, persamaan yang digunakan untuk menganalisa data (Rudianto, 2009 : 54) sebagai berikut: $Y=a+b X$.

Anggaran Produksi yaitu penjualan yang direncanakan, volume persediaan barang pada awal periode dan volume persediaan barang pada akhir periode tertentu (Rudianto, 2009 : 81). Anggaran biaya bahan baku, ditentukan oleh kebutuhan bahan baku dari setiap unit produk yang dihasilkan perusahaan, dikalikan dengan volume produksi, sehingga ditemukan volume total bahan baku untuk periode tersebut. Kebutuhan total bahan baku untuk produksi tersebut, ditambah dengan persediaan bahan baku yang diinginkan pada akhir periode tersebut dan dikurangi dengan persediaan bahan baku yang direncanakan pada awal periode.

Dari penjumlahan dan pengurangan tersebut akan diperoleh volume bahan baku yang direncanakan untuk dibeli, dikalikan dengan harga bahan baku per unitnya akan diperoleh nilai pembelian bahan baku yang direncanakan (Rudianto, 2009 : 84). Anggaran biaya tenaga kerja ditentukan dari mengkalikan upah yang dibayarkan dengan satuan tertentu. Satuan yang digunakan untuk menghitung dasar penetapan pembayaran tenaga kerja tersebut disebut tarif biaya tenaga kerja (Rudianto: 2009).

Anggaran biaya pemasaran mencakup keseluruhan biaya yang berkaitan dengan proses penjualan dan pendistribusian produk perusahaan (Rudianto: 2009). Aktivitas administrasi dan umum mencakup keseluruhan aktivitas umum perusahaan di luar aktivitas produksi dan pemasaran yang biasanya besar jumlahnya tidak dipengaruhi oleh kegiatan yang lain (Rudianto: 2009).

Metode yang digunakan untuk menentukan anggaran laba rugi ialah metode a posteriori, dimana metode ini digunakan pada jumlah laba yang ditetapkan setelah proses perencanaan secara keseluruhan. Metode penyusunan anggaran laba dilakukan setelah anggaran operasional disusun, dan metode ini menggunakan anggaran penjualan sebagai titik tolak penyusunan anggaran operasional (Rudianto: 2009). Metode paling sederhana untuk penyusunan proyeksi neraca dengan mengunakan persamaan akuntansi dasar yaitu, Aktiva= Kewajiban + Ekuitas (Rudianto: 2009).

Setelah penentuan proyeksi neraca, dihitung dan dicari rasio keuangan dari UMKM untuk tahun 2016 dan tahun 2017. Rasio keuangan dihitung untuk menentukan baik tidaknya sebuah anggaran. 
Tabel 1. Rasio Keuangan Perusahaan

\begin{tabular}{ll}
\hline \multicolumn{1}{c}{ Jenis Rasio } & \multicolumn{1}{c}{ Rumus } \\
\hline Rasio Likuiditas & Nilai Ideal dari rasio ini minimum 150\%, semakin besar \\
& semakin baik dan perusahaan dalam kondisi sehat \\
Current Ratio & Aktiva lancar/ Hutang Lancar x 100\% \\
Cash Ratio & Kas + Efek/Hutang Lancar x 100\% \\
Quick Ratio & Kas + Efek + Piutang/Hutang Lancar x 100\% \\
Rasio Profitabilitas & Semakin tinggi nilai presentase semakin baik, dengan \\
& perbandingan rata rata industri. \\
Gross Profit Margin & Penjualan Netto - HPP /Penjualan Netto x 100\% \\
Operating Income Ratio & Penjualan Netto - HPP - Biaya Adm dan umum /Penjualan \\
& Netto x 100\% \\
Net Profit Margin & Laba Bersih Setelah Pajak (EAT)/ Penjualan Netto x 100\% \\
\hline
\end{tabular}

Tabel 2. Rasio Keuangan Perusahaan

\begin{tabular}{ll}
\hline \multicolumn{1}{c}{ Jenis Rasio } & \multicolumn{1}{c}{ Rumus } \\
\hline Earning Power of Total Investment (BEP) & EBIT / jumlah aktiva x 100\% \\
Rate of Return Investment (ROI) & EAT / Jumlah Aktiva x100\% \\
Rate of Return on Net Worth & EAT / Jumlah Modal Sendiri x 100\% \\
Ratio Solvabilitas & Semakin Tinggi Semakin buruk \\
& kemampuan perusahaan untuk membayar \\
& kewajiban jangka panjang, maksimal 200\% \\
Total Debt to Assets Ratio & Total Hutang / Total Aktiva x 100\% \\
Total Debt to Equity Ratio & Total Hutang / Modal Sendiri x 100\% \\
Rasio Aktivitas & Semakin Tinggi semakin baik dg \\
& perbandingan rata rata industri \\
Total Assets Turn Over & Penjualan / Total Aktiva \\
Working Capital Turn Over & Penjualan / Modal Kerja Bersih (AL-HL) \\
Fixed Assets Turn Over & Penjualan / Aktiva Tetap \\
Inventory Turn Over & Penjualan / Persediaan \\
\hline
\end{tabular}

\section{HASIL PENELITIAN DAN PEMBAHASAN}

Proyeksi pada anggaran penjualan digunakan metode least square, data yang digunakan dalam metode ini merupakan data penjualan dari batik kecamatan Blimbing Malang setiap tahun, dimana penjualan setiap tahun dapat dilihat pada tabel sebagai berikut:
Tabel 3. Penjualan tahun 2011-2015

\begin{tabular}{ccccc}
\hline Tahun & $\begin{array}{c}\text { Penjualan } \\
\text { (Y) }\end{array}$ & $\mathrm{X}$ & $\mathrm{XY}$ & $\mathrm{X} 2$ \\
\hline 2011 & 30 & -2 & -60 & 4 \\
2012 & 36 & -1 & -36 & 1 \\
2013 & 48 & 0 & 0 & 0 \\
2014 & 70 & 1 & 70 & 1 \\
2015 & 98 & 2 & 196 & 4 \\
Total & 282 & & 170 & 10 \\
\hline
\end{tabular}


Proyeksi penjualan tahun 2016 (t2016 = 3), jadi proyeksi penjualan 2016 sebagai berikut $Y=a+b X=$ $56,4+17(3)=107,4$. Penjualan yang diproyeksikan pada tahun 2016 sebanyak 107,4 atau 108 unit @Rp. $550.000=$ Rp. 59.070.000. Sedangkan, proyeksi penjualan tahun 2017 (t2017 = 4), jadi proyeksi penjualan 2017 sebagai berikut: $Y=a$ $+b X=56,4+17(4)=124,4$.

Tabel 4. Anggaran Produksi Tahun 2016 dan 2017

\begin{tabular}{lcc}
\hline Keterangan & $\begin{array}{c}2016 \\
\text { Produk } \\
\text { (unit) }\end{array}$ & $\begin{array}{c}2017 \\
\text { Produk } \\
\text { (unit) }\end{array}$ \\
\hline $\begin{array}{l}\text { Rencana } \\
\text { Penjualan } \\
\text { Rencana } \\
\text { persediaan }\end{array}$ & 107,4 & 124,4 \\
$\begin{array}{l}\text { Akhir } \\
\text { Jumlah }\end{array}$ & 10,74 & 12,44 \\
$\begin{array}{l}\text { kebutuhan } \\
\text { (Persediaan }\end{array}$ & 118,14 & 136,84 \\
$\begin{array}{l}\text { Awal) } \\
\text { Rencana }\end{array}$ & $(10)$ & $(10,74)$ \\
Produksi & 108,14 & 126,1 \\
\hline
\end{tabular}

Kebutuhan bahan baku yang akan digunakan dalam produksi pada tahun 2016 untuk 108 kain batik sebanyak; 270,35 meter kain, 216,28 gram malam, dan 8110,5 gram pewarna total biaya pembelian bahan baku sebesar Rp. 13.136.514. Sedangkan produksi tahun 2017 sebanyak 126 kain batik membutuhkan 315,25. Penjualan yang diproyeksikan pada tahun 2017 sebanyak 124,4 atau 125 unit@Rp. 550.000=Rp. 68.420.000.

Perhitungan anggaran produksi membutuhkan elemen persediaan akhir yang diinginkan dan persediaan awal tahun, pada batik blimbing ditentukan bahwa persediaan akhir diinginkan tahun 2016 sebanyak 20 unit dan persediaan awal pada tahun 2016 sebanyak 10 unit (sumber data sekunder). pada batik blimbing ditentukan bahwa persediaan akhir diinginkan tahun 2017 sebanyak 20 unit dan persediaan awal pada tahun 2017 sebanyak 20 unit (sumber data 2016). Berdasarkan seumber data sekunder yang didapat, maka perhitungan anggaran produksi tahun 2016 sebagai berikut: meter kain, 252,2 gram malam, dan 9457,5 gram pewarna dengan total biaya pembelian bahan baku sebesar Rp. 18.033.336. Anggaran bahan baku yang habis digunakan untuk produksi 108 kain batik pada tahun 2016 sebesar Rp. 5.407.000 untuk kain, Rp. 1.730.240 untuk malam dan Rp. 8.110.500 untuk pewarna. Anggaran keseluruhan bahan baku yang habis dipakai sebesar Rp. 15.247.740, Sedangkan untuk anggaran bahan baku yang habis digunakan untuk produksi 126 kain batik pada tahun 2017 sebesar Rp. 6.305.000 untuk kain, Rp. 2.017.600 untuk malam dan Rp. 9.457.500 untuk pewarna. Anggaran keseluruhan bahan baku yang habis dipakai sebesar $\mathrm{Rp}$. 17.780.100,-.

Anggaran biaya tenaga kerja dengan jumlah jam kerja 3893,04 dan tarif per jam kerja sebesar Rp. 2500 menghasilkan perhitungan sebesar Rp. 9.732.600,- pada tahun 2016 dan Rp. Rp. 11.349.000,- pada tahun 2017 dengan jumlah jam kerja sebesar 4539,6 jam. Menggunakan dasar perhitungan jumlah jam kerja langsung, maka untuk memproduksi 108,14 unit pada tahun 2016, membutuhkan biaya overhead sebesar Rp. 2.904.640,- sedangkan pada tahun 2017, untuk memproduksi 126,1 unit, biaya 
overhead untuk tahun 2017 senilai Rp. 3.387.046,-

Anggaran Biaya Pemasaran untuk tahun 2016, yaitu Biaya iklan sebesar Rp. 600.000,-. Dan untuk tahun 2017 diasumsikan sama seperti tahun 2016 yang memiliki biaya iklan sebesar Rp. 600.000,-.Aktivitas administrasi dan umum yang mencakup dalam usaha ini yaitu sebagai berikut: Perhitungan selanjutnya adalah menentukan anggaran laba-rugi, sebelum menghitung anggaran laba- rugi, perlu ditentukan Harga Pokok Produksi (HPP).

Harga pokok penjualan yang dianggarkan untuk tahun 2016 sebesar Rp. 29.589.206,- yang merupakan penjumlahan dari biaya Harga pokok produksi, Persediaan awal dan dikurangi persediaan akhir yang dianggarkan. Kemudian diketahui laba kotor sebesar Rp. 29.480.794,-. Setelah laba kotor diketahui kemudian dikurangi dengan biaya administrasi \& umum dijumlah dengan biaya pemasaran yang berjumlah Rp. 21.600.000,-. Hasilnya merupakan laba bersih tahun berjalan 2016 sebesar Rp. 7.880.794,--

Kemudian

penyusunan anggaran laba rugi untuk tahun 2017 dapat dinyatakan bahwa harga pokok penjualan yang dianggarkan untuk tahun 2017 sebesar Rp. 31.327.910,yang merupakan penjumlahan dari biaya Harga pokok produksi, Persediaan awal dan dikurangi persediaan akhir yang dianggarkan. Kemudian diketahui laba kotor sebesar Rp. 37.092.090. Setelah laba kotor diketahui kemudian dikurangi dengan biaya administrasi \& umum dijumlah dengan biaya pemasaran yang berjumlah Rp. 21.600.000. Hasilnya merupakan laba bersih tahun berjalan 2016 sebesar Rp. 15.492.090,--

Hasil peramalan kas selama dua periode tahun 2016 dan tahun 2017, UKM hanya memenuhi aliaran kas dari kegiatan operasional yang menghasilkan UKM, saldo kas akhir sebesar Rp. 38.475.246,- untuk tahun 2016 sedangkan untuk tahun 2017 kas akhir sebesar Rp 40.829.618. Sedangkan untuk aktivitas investasi dan aktivitas keuangan UKM belum memiliki kegiatan kas untuk dua katagori tersebut. Proyeksi neraca pada tahun 2016 dan tahun 2017 mengalami penurunan sebesar Rp. 832.462 .568 (2016) dan Rp. 807.887.100 (2017).

\section{SIMPULAN}

Berdasarkan hasil penelitian dan pembahasan yang dijelaskan pada bab sebelumnya, maka dapat diambil kesimpulan bahwa pada tahun 2016 penjualan mengalami kenaikan jumlah barang. Dari tahun 2015 sebanyak 98 lembar kain batik menjadi 108,14 pada tahun 2016. Namun mengalami penurunan dalam prosentase kenaikan penjualan pada tahun 2015 yang mencapai kenaikan penjualan sebesar $28 \%$ dari tahun 2014. Sedangkan pada tahun 2016 prosentase kenaikan penjualan hanya sebesar 9,4\%, dari tahun 2015. Ini menunjukkan penurunan penjualan sebesar 9\% dari tahun 2015.

Pada tahun 2017 penjualan mengalami kenaikan pada jumlah barang yang dijual. Dari tahun 2016 sebanyak 108,14 lembar kain batik menjadi 126,1 lembar kain batik, yang berarti memiliki kenaikan prosentase sebesar $17 \%$ dari tahun 
2016. Hal ini menunjukkan bahwa ada perubahan yang baik dari petumbuhan penjualan untuk tahun 2016 ke tahun 2017.

Anggaran tahun 2016 dan tahun 2017 yang telah diproyeksikan dalam penelitian ini masih belum bisa mememenuhi target UKM. Target yang ingin ditempuh adalah kenaikan prosentase penjualan dari tahun ke tahun selalu meningkat. Namun anggaran ini bisa sebagi acuan untuk menentukan dan memproyeksikan lagi anggaran tahun 2016 dan 2017 lebih baik lagi. UMKM memiliki rasio keuangan yang kurang baik untuk proyeksi kedepannya.

\section{DAFTAR PUSTAKA}

Agus Any, 2003, Anggaran Perusahaan; AK Group, Yogyakarta

Ahyari Agus, 1988, Anggaran Perusahaan Pendekatan

Kuantitatif, BPFE, Anggota IKAPI, Yogyakarta.

Djauhari Vika Maisuri. 2009.
Analisis Anggaran Biaya Operaional Pada PT. (PERSERO) Pelabuhan Indonesia I Medan. Universitas Sumatera Utara, Medan.

Hansen dan Mowen, 2007, Accounting Managerial; Eight Edition, Cengage Learning Asia Pte Ltd. Singapore. Diterjemahkan oleh Deny Arnos. 2009, Penerbit Salemba Empat. Jakarta.

Mursidi, 2012, Anggaran Perusahaan Budgeting, UMM Press, Malang

Rudianto, 2009, Penganggarn Perusahaan Konsep dan Teknik Penyusunan Anggaran; Penerbit Erlangga, Jakarta.

Siregar Nurhasanah, 2009, Analisis Perencanaan dan Pengawasan Laba Pada PT. Pertani (Persero) Kantor Cabang Pemasaran Sumatera Utara. Universitas Sumatera Utara, Medan.

Sugiyono, 2014, Metode penelitian Kuantitatif, Kualitatif, dan R\&D, Alfabeta, Bandung. 